\title{
Pengaruh Pemberian Pupuk Kandang Kotoran Sapi Terhadap Pertumbuhan Anakan Gaharu Beringin (Aquilaria malaccensis) Pada Tanah Podsolik Merah Kuning
}

\author{
Kamaludin \\ Fakultas pertanian Universitas kapuas sintang \\ e-mail : kamaludinkamal27@yahoo.co.id
}

\begin{abstract}
Abstrak:Penelitian ini bertujuan untuk mengetahui pengaruh pemberian pupuk kandang kotoran Sapi dan dosis yang terbaik dalam mempengaruhi pertumbuhan anakan Gaharu Beringin (Aquilaria malaccensis) pada tanah Podsolik Merah Kuning. Metode yang digunakan dalam penelitian ini adalah pola dasar Rancangan Acak Lengkap (RAL) dengan perlakuan tunggal adalah komposisi media tanam yang terdiri dari 4 taraf yaitu : Tanpa Pupuk/Kontrol (S0), Pupuk kandang kotoran Sapi 100 gram per anakan (S1), Pupuk kandang kotoran Sapi 200 gram per anakan (S2) dan Pupuk kandang kotoran Sapi 300 gram per anakan (S3). Rancangan ini dipilih karena anakan Gaharu Beringin dan alat yang digunakan dalam penelitian relatif homogen (seragam)

Hasil penelitian diketahui bahwa pemberian pupuk kandang kotoran Sapi berpengaruh sangat signifikan terhadap pertambahan tinggi dan pertambahan jumlah daun anakan Gaharu Beringin pada tanah Podsolik Merah Kuning. Perlakuan berupa pemberian pupuk kandang kotoran Sapi sebanyak 300 gram per anakan (S3) adalah yang terbaik dibandingkan dengan perlakuan lainnya, untuk meningkatkan pertambahan tinggi dengan rerata 4,50 $\mathrm{cm}$ dan pertambahan jumlah daun anakan Gaharu Beringin dengan rerata 4,67 helai.
\end{abstract}

Kata Kunci : Pupuk Kandang Kotoran Sapi, Tinggi dan Jumlah Daun, Anakan Gaharu Beringin serta Tanah Podsolik Merah Kuning

\section{Pendahuluan}

Pohon Gaharu bagi masyarakat Kalimantan Barat adalah sebutan untuk pohon yang dapat menghasilkan gaharu. Pohon penghasil gaharu ini banyak dijumpai pada hutan yang belum dijadikan sebagai lahan perkebunan bagi masyarakat, dengan perkembangbiakan yang terjadi secara alami dari alam. Pohon Gaharu dapat tumbuh dan berkembang pada berbagai variasi kondisi struktur dan tekstur tanah, baik pada lahan subur, sedang hingga lahan marginal. Pohon ini dapat dijumpai pada ekosistem hutan rawa, gambut, hutan dataran rendah atau hutan pegunungan, bahkan dijumpai pada lahan berpasir berbatu yang ekstrim.

Sejalan dengan perkembangan ilmu dan teknologi industri kimia dan farmasi serta didukung berkembangnya paradigma dunia kedokteran dan pengobatan untuk kembali memanfaatkan bahan tumbuhan alami, produk gaharu selain dibutuhkan 
Pengaruh Pemberian Pupuk Kandang Kotoran Sapi Terhadap Pertumbuhan Anakan Gaharu Beringin (Aquilaria malaccensis) Pada Tanah Podsolik Merah Kuning

sebagai bahan industri parfum dan kosmetika, juga banyak dibutuhkan sebagai bahan obat herbal, untuk pengobatan stress, asma, rheumatik, radang ginjal dan lambung, bahan anti biotik TBC, serta tumor dan kanker.( Purwanto D. B, 2008).

Potensi dan nilai ekonomis yang tinggi dari pohon Gaharu dalam bentuk gaharu, telah memicu masyarakat untuk berupaya mencari di seluruh wilayah hutan alam yang masih tersedia. Upaya ini jika terus dilakukan tentu akan mengancam keberadaan jenis pohon Gaharu di alam, sehingga perlu tindakan budidaya sebagai langkah awal untuk menjaga kelestarian sekaligus sebuah harapan untuk mendapatkan penghasilan. Dalam upaya budidaya, menyiapkan bibit yang siap tanam dalam jumlah yang banyak dan berkualitas adalah sebagai langkah awal yang menentukan tingkat keberhasilan usaha ini. Untuk menghasilkan bibit yang berkualitas, maka pemeliharaan dengan pemberian pupuk sangat diperlukan. Pupuk yang digunakan dapat berupa pupuk organik maupun pupuk anorganik.

\section{Metodologi penelitian}

Metode yang digunakan dalam penelitian ini adalah pola dasar
Rancangan Acak Lengkap (RAL) dengan perlakuan tunggal adalah komposisi media tanam yang terdiri dari 4 taraf yaitu : Tanpa Pupuk/Kontrol (S0), Pupuk kandang kotoran Sapi 100 gram per anakan (S1), Pupuk kandang kotoran Sapi 200 gram per anakan (S2) dan Pupuk kandang kotoran Sapi 300 gram per anakan (S3).

\section{Populasi dan Sampel}

Jumlah populasi dalam penelitian ini sebanyak 96 anakan Gaharu Beringin yang berasal dari 4 taraf perlakuan pupuk kandang kotoran Sapi. Masing-masing perlakuan diulang sebanyak 6 kali dan setiap ulangan terdapat 4 anakan. Sampel dalam penelitian ini diambil sebanyak 2 anakan setiap ulangan sehingga anakan Gaharu Beringin yang diamati sebanyak $4 \times 6$ ulangan $\times 2$ bibit $=48$ anakan.

\section{Bahan dan alat penelitian}

Bahan dan alat yang digunakan dalam penelitian ini adalan semua anakan Gaharu Beringin, dalah Pupuk kandang kotoran Sapi, Air, Polybag ukuran $20 \mathrm{x}$ $20 \times 20 \mathrm{~cm}$, Paranet dengan intensitas 75\%, Parang, sabit, cangkul, Gembor, Kamera, Alat tulis Mistar ukur, Timbangan Fungisida, 
Pengaruh Pemberian Pupuk Kandang Kotoran Sapi Terhadap Pertumbuhan Anakan Gaharu Beringin (Aquilaria malaccensis) Pada Tanah Podsolik Merah Kuning

Hasil Dan Pembahasan

Hasil Penelitian

Data hasil rerata pertambahan tinggi anakan Gaharu Beringin pada tanah Podsolik Merah Kuning pada tabel 1. Dari data pada table 1,selanjutnya dilakukan analisis sidik ragam. Hasil analisis sidik ragam dapat dilihat pada tabel 2 .

Tabel 1. Data Rerata Pertambahan Tinggi Anakan Gaharu Beringin Selama Penelitian

\begin{tabular}{|c|c|c|c|c|c|c|c|c|}
\hline \multirow{2}{*}{ Perlakuan } & \multicolumn{6}{|c|}{ Ulangan } & \multirow{2}{*}{ Jumlah } & \multirow{2}{*}{ Rerata } \\
\hline & 1 & 2 & 3 & 4 & 5 & 6 & & \\
\hline So & 0 & 0 & 0 & 1 & 1 & 1 & 3 & $\mathbf{0 , 5 0}$ \\
\hline S1 & 2 & 2 & 2 & 2 & 3 & 3 & 14 & 2,33 \\
\hline S2 & 3 & 3 & 3 & 3 & 3 & 5 & 20 & $\mathbf{3 , 3 3}$ \\
\hline S3 & 4 & 4 & 4 & 5 & 5 & 5 & 27 & 4,50 \\
\hline Jumlah & 9 & 9 & 9 & 11 & 12 & 14 & 64 & 10,67 \\
\hline
\end{tabular}

Tabel 2. Hasil Analisis Sidik Ragam

\begin{tabular}{|c|c|c|c|c|c|c|}
\hline \multirow{2}{*}{$\begin{array}{c}\text { Sumber } \\
\text { Keragaman }\end{array}$} & \multirow{2}{*}{$\begin{array}{l}\text { Derajat } \\
\text { Bebas }\end{array}$} & \multirow{2}{*}{$\begin{array}{l}\text { Jumlah } \\
\text { Kuadrat }\end{array}$} & \multirow{2}{*}{$\begin{array}{c}\text { Kwadrat } \\
\text { Tengah }\end{array}$} & \multirow[t]{2}{*}{ F. Hitung } & \multicolumn{2}{|c|}{ F tabel } \\
\hline & & & & & $5 \%$ & $1 \%$ \\
\hline Perlakuan & 3 & 51,67 & 17,22 & $14,29 * *$ & 3,10 & 4,94 \\
\hline Galat & 20 & 24,10 & 1,20 & & & \\
\hline Total & 23 & 75,76 & & & & \\
\hline
\end{tabular}

Keterangan : ** : Berpengaruh Sangat Signifikan

Berdasarkan hasil analisis sidik ragam sebagaimana yang dapat dilihat pada tabel.2 tersebut, maka diketahui bahwa pemberian pupuk Kandang Kotoran Sapi memberikan pengaruh yang sangat signifikan terhadap pertambahan tinggi anakan Gaharu Beringin pada tanah Podsolik Merah Kuning. Untuk mengetahui dosis perlakuan pemberian Pupuk Kandang Kotoran Sapi yang terbaik dalam mempengaruhi pertambahan tinggi anakan Gaharu Beringin, maka dilakukan pengujian terhadap rerata perbedaan masing-masing perlakuan dengan menggunakan Uji Beda Nyata Terkecil (BNT) pada taraf nyata 5\% dan 1\%. Hasil Uji BNT perbedaan masingmasing perlakuan pupuk Kandang Kotoran Sapi terhadap pertambahan tinggi anakan Gaharu Beringin pada tanah Podsolik Merah Kuning dapat dilihat pada tabel 3 . 
Pengaruh Pemberian Pupuk Kandang Kotoran Sapi Terhadap Pertumbuhan Anakan Gaharu Beringin (Aquilaria malaccensis) Pada Tanah Podsolik Merah Kuning

Tabel 3. Hasil Uji Beda Nyata Terkecil

\begin{tabular}{|l|r|r|r|r|r|}
\hline \multirow{2}{*}{ Perlakuan } & \multirow{2}{*}{ Rerata } & \multicolumn{5}{|c|}{ Beda } \\
\cline { 3 - 6 } & & S0 & S1 & S2 & S3 \\
\hline S0 & 0,50 & & & & \\
\hline S1 & 2,33 & $1,83^{* *}$ & & & \\
\hline S2 & 3,33 & $2,83^{* *}$ & $1,00^{\text {ns }}$ & & \\
\hline S3 & 4,50 & $4,00^{* *}$ & $2,17^{* *}$ & $1,17^{\text {ns }}$ & - \\
\hline \multicolumn{5}{|c|}{ BNT 5\% : 1,32 } & BNT 1\%: 1,80 \\
\hline
\end{tabular}

Keterangan : $* *=$ Berbeda sangat signifikan

ns $=$ Tidak berbeda signifikan

Hasil uji BNT sebagaimana pada tabel 3, diketahui bahwa pemberian pupuk Kandang Kotoran Sapi dengan dosis 300 gram per anakan (S3), merupakan perlakuan terbaik untuk meningkatkan pertambahan tinggi anakan Gaharu Beringin, tetapi perlakuan tersebut tidak signifikan jika dibandingkan dengan perlakuan S2 (pupuk Kandang Kotoran Sapi dengan dosis 200 gram per anakan) . Hal ini terlihat dengan jelas bahwa S3 berbeda sangat signifikan dengan perlakuan S1 (pupuk Kandang Kotoran Sapi dengan dosis 100 gram per anakan) dan perlakuan S0 (tanpa Pupuk), tetapi tidak berbeda secara signifikan dibandingkan dengan perlakuan S2 (pupuk Kandang Kotoran Sapi dengan dosis 200 gram per anakan). Perlakuan S2 berbeda sangat signifikan dibandingkan dengan S0, tetapi tidak berbeda secara signifikan terhadap perlakuan S1.

Pertambahan jumlah daun anakan Gaharu Beringin merupakan hasil perhitungan yang didapatkan dengan cara mengurangi jumlah daun anakan pada akhir penelitian dengan jumlah daun anakan pada awal penelitian.

Tabel 4. Data Rerata Pertambahan Jumlah Daun Anakan Gaharu Beringin

\begin{tabular}{|c|c|c|c|c|c|c|c|c|}
\hline \multirow{2}{*}{ Perlakuan } & \multicolumn{6}{|c|}{ Ulangan } & \multirow{2}{*}{ Jumlah } & \multirow{2}{*}{ Rerata } \\
\hline & 1 & 2 & 3 & 4 & 5 & 6 & & \\
\hline So & 1 & 1 & 1 & 1 & 1 & 1 & 6 & 1,00 \\
\hline S1 & 2 & 2 & 2 & 2 & 3 & 3 & 14 & 2,33 \\
\hline $\mathbf{S 2}$ & 3 & 3 & 3 & 3 & 3 & 4 & 19 & 3,17 \\
\hline S3 & 4 & 4 & 5 & 5 & 5 & 5 & 28 & 4,67 \\
\hline Jumlah & 10 & 10 & 11 & 11 & 12 & 13 & 67 & 11,17 \\
\hline
\end{tabular}


Pengaruh Pemberian Pupuk Kandang Kotoran Sapi Terhadap Pertumbuhan Anakan

Gaharu Beringin (Aquilaria malaccensis) Pada Tanah Podsolik Merah Kuning

Tabel 5. Hasil Analisis Sidik Ragam

\begin{tabular}{|c|c|c|c|c|c|c|}
\hline \multirow{2}{*}{$\begin{array}{c}\text { Sumber } \\
\text { Keragaman }\end{array}$} & \multirow{2}{*}{$\begin{array}{c}\text { Derajat } \\
\text { Bebas }\end{array}$} & \multirow{2}{*}{$\begin{array}{l}\text { Jumlah } \\
\text { Kuadrat }\end{array}$} & \multirow{2}{*}{$\begin{array}{c}\text { Kwadrat } \\
\text { Tengah }\end{array}$} & \multirow[t]{2}{*}{ F. Hitung } & \multicolumn{2}{|c|}{ F tabel } \\
\hline & & & & & $5 \%$ & $1 \%$ \\
\hline Perlakuan & 3 & 42,46 & 14,15 & \multirow[t]{3}{*}{$80,87 * *$} & \multirow[t]{3}{*}{3,10} & \multirow[t]{3}{*}{4,94} \\
\hline Galat & 20 & 350 & 018 & & & \\
\hline Total & 23 & 4596 & & & & \\
\hline \multicolumn{7}{|c|}{$\mathrm{KK}=3,75 \%$} \\
\hline
\end{tabular}

Keterangan : ** : Berpengaruh Sangat Signifikan

Berdasarkan hasil analisis sidik ragam sebagaimana yang dapat dilihat pada tabel 5 tersebut, maka diketahui bahwa pemberian pupuk Kandang Kotoran Sapi memberikan pengaruh yang sangat signifikan terhadap pertambahan jumlah daun anakan Gaharu Beringin pada tanah Podsolik Merah Kuning. Untuk mengetahui dosis perlakuan pemberian Pupuk Kandang Kotoran Sapi yang terbaik dalam mempengaruhi pertambahan jumlah daun anakan Gaharu Beringin, maka dilakukan pengujian terhadap rerata perbedaan masing-masing perlakuan dengan menggunakan Uji Beda Nyata Terkecil (BNT) pada taraf nyata 5\% dan 1\%. Hasil Uji BNT perbedaan masingmasing perlakuan pupuk Kandang Kotoran Sapi terhadap pertambahan jumlah daun anakan Gaharu Beringin pada tanah Podsolik Merah Kuning dapat dilihat pada tabel 6 .

Tabel 6. Hasil Uji Beda Nyata Terkecil

\begin{tabular}{|c|c|c|c|c|c|}
\hline \multirow[b]{2}{*}{ Perlakuan } & \multirow[b]{2}{*}{ Rerata } & \multicolumn{4}{|c|}{ Beda } \\
\hline & & So & S1 & S2 & S3 \\
\hline S0 & 1,00 & & & & \\
\hline S1 & 2,33 & $1,33 * *$ & & & \\
\hline S2 & 3,17 & $2,17 *$ & $0.84 * *$ & & \\
\hline S3 & 4,67 & $3,67 * *$ & $2,34 * *$ & $1,50^{* * *}$ & - \\
\hline
\end{tabular}

Keterangan : $* *=$ Berbeda sangat signifikan

$\mathrm{ns}=$ Tidak berbeda signifikan

Hasil uji BNT sebagaimana pada tabel 6, diketahui bahwa pemberian pupuk Kandang Kotoran Sapi dengan dosis 300 gram per anakan (S3), merupakan perlakuan terbaik untuk PIPER No.26 Volume 14 April 2018 meningkatkan pertambahan jumlah daun anakan Gaharu Beringin. Hal ini terlihat dengan jelas bahwa S3 berbeda sangat signifikan jika dibandingkan dengan perlakuan S2 (pupuk Kandang 
Pengaruh Pemberian Pupuk Kandang Kotoran Sapi Terhadap Pertumbuhan Anakan Gaharu Beringin (Aquilaria malaccensis) Pada Tanah Podsolik Merah Kuning

Kotoran Sapi dengan dosis 200 gram per anakan). Perlakuan S3 juga berbeda sangat signifikan dengan perlakuan $\mathrm{S} 1$ (pupuk Kandang Kotoran Sapi dengan dosis 100 gram per anakan) dan perlakuan S0 (tanpa Pupuk). Perlakuan S2 berbeda sangat signifikan dibandingkan dengan S0, dan dengan perlakuan S1 serta perlakuan S1 berbeda sangat signifikan terhadap perlakuan S0.

\section{Pembahasan}

Berdasarkan hasil analisis sidik ragam sebagaimana tabel 2 diketahui bahwa pemberian pupuk Kandang Kotoran Sapi memberikan pengaruh sangat signifikan terhadap pertambahan tinggi anakan Gaharu Beringin pada tanah Podsolik Merah Kuning selama penelitian. Selanjutnya berdasarkan uji BNT sebagaimana tabel 3. diketahui bahwa pemberian pupuk Kandang Kotoran Sapi dengan dosis 300 gram per anakan (S3), merupakan perlakuan yang terbaik untuk meningkatkan pertambahan tinggi anakan Gaharu Beringin dibandingkan dengan perlakuan lainnya, dengan rerata pertambahan tinggi $4,50 \mathrm{~cm}$. Hal ini mengindikasikan bahwa pemberian pupuk Kandang Kotoran Sapi dengan dosis tersebut adalah yang terbaik sekaligus paling tepat, karena pada perlakuan tersebut telah terjadi pertumbuhan yang maksimal.

Pemupukan adalah salah satu cara untuk mengatasi tanah yang miskin unsur hara, sehingga menjadi tanah yang subur dan dapat memacu pertumbuhan tanaman di atasnya. Tanah Podsolik Merah Kuning adalah salah satu tanah yang miskin akan unsur hara, dengan demikian setiap upaya budidaya tanaman di atasnya agar dapat berhasil sesuai harapan, maka harus diberikan hara melalui pemupukan. Tanaman yang dapat tumbuh dengan baik pada tanah ini, berarti kebutuhan haranya telah tercukupi. Hasil penelitian yang menunjukkan bahwa perlakuan pemberian 300 gram pupuk kandang kotoran Sapi per anakan (S3) adalah yang terbaik dalam memacu pertumbuhan tinggi anakan Gaharu Beringin, mengindikasikan bahwa jumlah pupuk yang diberikan tersebut mampu merubah tanah yang miskin unsur hara menjadi tanah yang subur, sehingga pertumbuhan tanaman di atasnya menjadi maksimal. Hal ini terlihat dengan jelas, pada pemberian pupuk Kandang Kotoran Sapi sebanyak 300 gram per anakan (S3) telah 
Pengaruh Pemberian Pupuk Kandang Kotoran Sapi Terhadap Pertumbuhan Anakan Gaharu Beringin (Aquilaria malaccensis) Pada Tanah Podsolik Merah Kuning

mengakibatkan pertumbuhan tinggi anakan Gaharu Beringin menjadi paling maksimal bila dibandingkan dengan perlakuan pemberian pupuk Kandang Kotoran Sapi lainnya. Meskipun demikian, jika perlakuan S3 dibandingkan dengan perlakuan S2 ternyata tidak ada perbedaan yang signifikan. Terhadap kenyataan ini dapat diduga karena waktu penelitian yang singkat, sehingga pertumbuhan tinggi belum optimal. Dugaan ini didasarkan pada perlakuan S3 memberikan pengaruh yang sangat signifikan dan terbaik dibanding perlakuan lainnya terhadap pertambahan jumlah daun anakan Gaharu Beringin, sehingga dengan jumlah daun yang banyak memungkinkan pertumbuhan tinggi batang akan maksimal.

Pupuk yang diberikan pada tanaman jika belum mencukupi kebutuhan, maka pertumbuhan tanaman tidak akan optimal sebaliknya jika diberikan dalam jumlah yang sedikit pertumbuhannya pun tidak akan optimal. Pemberian pupuk dengan takaran/dosis yang sesuai, itulah yang akan memberikan respon pertumbuhan yang maksimal bagi tanaman, dan ini ditunjukkan pada pemberian pupuk
Kandang Kotoran Sapi sebanyak 300 gam per anakan (S3). Pemberian pupuk yang mengandung $\mathrm{N}, \mathrm{P}$, dan $\mathrm{K}$ sangat berguna untuk menambah tinggi tanaman. Pemberian unsur $\mathrm{N}$ pada tahap perkembangan tanaman akan merangsang pertumbuhan dan pertambahan tinggi tanaman, sedangkan adanya unsur $\mathrm{K}$ merupakan sebagai pengimbang pengaruh $\mathrm{N}$ dan $\mathrm{P}$ serta meransang pertumbuhan akar.

Berdasarkan hasil analisis sidik ragam sebagaimana tabel 5 diketahui bahwa pemberian pupuk Kandang Kotoran Sapi memberikan pengaruh yang sangat signifikan terhadap pertambahan jumlah daun anakan Gaharu Beringin pada tanah Podsolik Merah Kuning selama penelitian. Selanjutnya berdasarkan uji BNT sebagaimana tabel 6. diketahui bahwa pemberian pupuk Kandang Kotoran Sapi dengan dosis 300 gram per anakan (S3), merupakan perlakuan yang terbaik untuk meningkatkan pertambahan jumlah daun anakan Gaharu Beringin dibandingkan dengan perlakuan lainnya, dengan rerata pertambahan jumlah daun sebanyak 4,67 helai.

Pemberian pupuk Kandang Kotoran Sapi dengan dosis 300 gram per anakan (S3) adalah yang paling optimal dalam 
Pengaruh Pemberian Pupuk Kandang Kotoran Sapi Terhadap Pertumbuhan Anakan Gaharu Beringin (Aquilaria malaccensis) Pada Tanah Podsolik Merah Kuning

memacu pertumbuhan jumlah daun anakan Gaharu Beringin pada tanah Podsolik Merah Kuning. Pemberian pupuk sebanyak 300 gram per anakan telah mencukupi kebutuhan tanaman, sehingga pertumbuhan menjadi optimal dibandingkan dengan perlakukan yang lainnya. Hal ini memberikan gambaran bahwa, bila pupuk diberikan dalam jumlah yang sesuai maka pertumbuhan tanaman akan optimal, sebaliknya jika pupuk yang diberikan belum mencukupi maka pertumbuhan tanaman tidak akan optimal. Hasil penelitian dengan menggunakan pupuk organik ini tidaklah sama dengan pengunaan pupuk kimia, dimana jika diberikan dalam jumlah yang berlebihan akan berdampak racun dan menghambat pertumbuhan tanaman. Mengenai hal ini ditegaskan oleh Yasman dan Smith (1988), yang menyatakan bahwa pemberian pupuk sangat memegang peranan penting. Konsentrasi yang terlalu rendah akan mengakibatkan pertumbuhan dan pertambahan tinggi menjadi lama, sedangkan konsentrasi yang terlalu tinggi akan berakibat racun bagi anakan tanaman, sehingga pertumbuhan dan perkem-bangannnya menjadi terhambat. Terhadap pupuk organik tidak dikenal dosis/takaran yang berlebihan, karena tanaman akan menyesuaikan kebutuhannya dan pupuk yang belum digunakan akan dimanfaatkan secara bertahap dan sebagian menjadi media tanam.

Kurang tersedianya unsur hara dapat mengakibatkan terhambatnya proses metabolisme dalam tubuh tanaman, keadaan ini pada akhirnya akan menghambat pembentukan akar, batang dan daun. Pertumbuhan dan perkembangan daun sangat dipengaruhi oleh akar tanaman. Apabila pertumbuhan akar terhambat maka akan menghambat pertumbuhan tanaman pada bagian atasnya. Terhambatnya pertumbuhan akar mengakibatkan terhambatnya pertumbuhan organ tanaman lainnya. Ketersedian unsur hara sangat mempengaruhi laju pertumbuhan suatu tanaman. Suatu kondisi yang sangat penting bagi pertumbuhan dan kesehatan tanaman adalah persediaan jumlah unsur hara yang sesuai, memadai dan seimbang secara tepat waktu yang bisa diserap langsung oleh tanaman. Kekurangan dan ketidakseimbangan unsur hara merupakan halangan utama bagi pertumbuhan tanaman. Ketersediaan unsur hara sangat tergantung pada kodisi umum tanah, kehidupan tanah 
Pengaruh Pemberian Pupuk Kandang Kotoran Sapi Terhadap Pertumbuhan Anakan Gaharu Beringin (Aquilaria malaccensis) Pada Tanah Podsolik Merah Kuning

dan pengolahan bahan organik. Oleh karena itu, untuk mendapatkan pertumbuhan yang maksimum mutlak diberikan unsur hara pada taraf optimum bagi tanaman tersebut.

Jaringan meristem pada ujungujung akar adalah sel- sel yang aktif terlibat dalam pembelahan dan pertumbuhan sel, sehingga penyerapan hara pada tanah akan menjadi lebih besar untuk proses metabolisme pada tanaman yang menghasilkan pertumbuhan termasuk pada daun. Hasil penelitian yang menunjukkan, bahwa terdapat pengaruh yang sangat signifikan mengenai pemberian pupuk Kandang Kotoran Sapi terhadap pertambahan tinggi dan jumlah helai daun, berarti pertumbuhan akar telah optimal, sehingga mampu merangsang pertumbuhan seluruh bagian vegetatif tanaman. Pemberian pupuk Kandang Kotoran Sapi seperti yang terlihat pada bagian hasil, memberikan pengaruh yang sangat signifikan terhadap pertambahan tinggi dan jumlah daun anakan Gaharu Beringin. Hal ini menunjukkan bahwa pemberian pupuk Kandang Kotoran Sapi mampu memberikan/menyuplai $\mathrm{N}$, $\mathrm{P}$, dan $\mathrm{K}$ serta unsur hara mikro secara optimum untuk pertumbuhan anakan Gaharu
Beringin, karena dari semua unsur hara yang dibutuhkan oleh tanaman, unsur $\mathrm{N}$, $\mathrm{P}$, dan $\mathrm{K}$ merupakan unsur - unsur utama yang diperlukan dalam jumlah yang paling banyak.

\section{Kesimpulan dan saran}

\section{Kesimpulan}

Berdasarkan hasil penelitian dan pengamatan, maka dapat disimpulkan sebagai berikut;

1. Pemberian pupuk kandang kotoran Sapi memberikan pengaruh yang sangat signifikan terhadap pertumbuhan tinggi dan jumlah daun anakan Gaharu Beringin (Aquilaria malaccensis) pada tanah Podsolik Merah Kuning.

2. Perlakuan pemberian Pupuk Kandang Kotoran Sapi dengan dosis 300 gram per anakan (S3) adalah yang terbaik dibandingkan dengan perlakuan lainnya, yaitu mampu meningkatkan pertambahan tinggi dengan rerata $4,50 \mathrm{~cm}$ dan pertambahan jumlah daun anakan Gaharu Beringin dengan rerata 4,67 helai. 
Pengaruh Pemberian Pupuk Kandang Kotoran Sapi Terhadap Pertumbuhan Anakan Gaharu Beringin (Aquilaria malaccensis) Pada Tanah Podsolik Merah Kuning

Saran

Perlu dilakukan kajian yang lebih mendalam untuk melihat pengaruh pemberian Pupuk Kandang Kotoran Sapi terhadap pertumbuhan anakan Gaharu Beringin yaitu dengan cara menambah lamanya waktu penelitian karena respon pupuk organik lebih lama dibandingkan dengan pupuk kimia dan terdapat indikasi pertumbuhan tinggi anakan yang belum optimal, sehingga didapatkan sebuah kesimpulan yang utuh.

\section{Daftar Pustaka}

Atmojo,K. S. 2003. Sudah Gaharu Super Pula. Pustaka Sinar Harapan, Jakarta.

Buckman, H.O, dan Brady, N.C. 1982. Ilmu Tanah. Diterjemahkan oleh Soegiman. Jakarta: Bharata Karya Aksara.

Foth. D.H. 1994. Dasar-Dasar Ilmu

Tanah. Jakarta: Erlangga.
Hanafiah, KA. 2008. Rancangan Percobaan. Jakarta : PT. Raja Grafindo Persada.

Harjadi, S.S. 1996. Pengantar Agronomi. Jakarta: PT. Gramedia Pustaka Utama.

Hyne, K., 1987. Tumbuhan Berguna Indonesia III. Departemen Kehutanan.

Purwanto D. B. 2008, Manfaat Gaharu. Penebar Swadaya. Jakarta

Suhadi Octen, 2006. Budi Daya Gaharu. Jakarta. Azka Press

Sumarna, Y. 2002. Budidaya Gaharu. Penebar Swadaya. Jakarta.

Sumarna, Y. 2012. Pembudidayaan Pohon Penghasil Gaharu. Departemen Kehutanan. Badan Penelitian Dan Pengembangan Kehutanan Pusat Litban Produktifitas Hutan. Bogor.

Sutedjo, 2002. Cara Praktis Membuat Kompos. Agromedia. Jakarta.

Wildan Djaja. 2008. Langkah Jitu Membuat Kompos dari Kotoran Ternak dan Sampah. Agromedia. Jakarta. Yasman dan Smith. 1988. Metode Pembuatan Stek Dipterocarpaceae. Balai Penelitian Kehutanan. Samarinda. 